\title{
Clinical and genetic aspects of testicular germ cell tumours
}

\author{
Martijn F. Lutke Holzik', ${ }^{1,2}$ Rolf H. Sijmons ${ }^{3}$, Josette E.H.M. Hoekstra-Weebers ${ }^{4,5}$, Dirk Th. Sleijfer ${ }^{6}$, Harald J. Hoekstra ${ }^{1}$ \\ 1Department of Surgical Oncology, University Medical Center Groningen, University of Groningen, Groningen, The Netherlands \\ 2Department of Surgery, Medisch Spectrum Twente, Enschede, The Netherlands \\ ${ }^{3}$ Department of Genetics, University Medical Center Groningen, University of Groningen, Groningen, The Netherlands \\ ${ }^{4}$ Wenckebach Institute, University Medical Center Groningen, University of Groningen, Groningen, The Netherlands \\ ${ }^{5}$ Comprehensive Cancer Center North-Netherlands, Groningen, The Netherlands \\ ${ }^{6}$ Department of Medical Oncology, University Medical Center Groningen, University of Groningen, Groningen, The Netherlands
}

Key words: testicular germ cell tumour, genetics, familial, therapy, review

Corresponding author: Martijn F. Lutke Holzik, MD, PhD, Medisch Spectrum Twente, Department of Surgery, P0 Box 50.000, 7500 KA Enschede, The Netherlands, phone: +31 53 4872510, fax: +31 53 4872526, e-mail: lutkeholzik@home.nl

Submitted: 1 February 2008

Accepted: 12 February 2008

\begin{abstract}
In this paper we review clinical and genetic aspects of testicular germ cell tumours (TGCTs). TGCT is the most common type of malignant disorder in men aged 15-40 years. Its incidence has increased sharply in recent years. Fortunately, survival of patients with TGCT has improved enormously, which can chiefly be attributed to the cisplatin-based polychemotherapy that was introduced in the nineteen eighties to treat patients with metastasized TGCT. In addition, new strategies have been developed in the surgical approach to metastasized/non-metastasized TGCT and alterations have been made to the radiotherapy technique and radiation dose for seminoma. Family history of TGCT is among the strongest risk factors for this tumour type. Although this fact and others suggest the existence of genetic predisposition to develop TGCT, no germline mutations conferring high risk of developing TGCT have been identified so far. A small deletion, referred to as $\mathrm{gr} / \mathrm{gr}$, identified on the $\mathrm{Y}$ chromosome is probably associated with only a modest increase in TGCT risk, and linkage of familial TGCT to the Xq27 region has not been confirmed yet. Whether highly penetrant TGCTpredisposing mutations truly exist or familial clustering of TGCT can be explained by combinations of weak predispositions, shared in utero or postnatal risks factors and coincidental somatic mutations is an intriguing puzzle, still waiting to be solved.
\end{abstract}

\section{Introduction}

Testicular tumours can be divided into germ cell tumours, stromal tumours and other tumours (e.g. malignant lymphomas). Tumours of paratesticular structures form a separate group. This review focuses solely on the testicular germ cell tumours (TGCT) seminoma and non-seminoma. TGCT are rare, but they are the most frequently occurring tumour in men aged between 15 and 40 years. In the Netherlands, 536 men were diagnosed with TGCT in 2003, while in 2004, 30 men died of this malignancy. Although the incidence of TGCT has increased sharply in recent years, survival of patients with TGCT has improved enormously. Five-year survival in the nineteen seventies was about $65 \%$ compared to more than $90 \%$ at 
present [1]. Improved survival can chiefly be attributed to the cisplatin-based polychemotherapy that was introduced in the nineteen eighties to treat patients with metastasized TGCT. In addition, new strategies have been developed in the surgical approach to metastasized/non-metastasized TGCT and alterations have been made to the radiotherapy technique and radiation dose for seminoma $[2,3]$. The progress in diagnosis, treatment and the subsequent treatment outcomes in patients with TGCT are the ultimate result of multidisciplinary teamwork. At the University Medical Center Groningen (UMCG), this multidisciplinary approach was started at the end of the nineteen seventies to provide every patient with tailored treatment. These accomplishments in the treatment of TGCT have led to the present goal of further optimising the treatment for TGCT, in which the research and treatment chiefly concentrate on reducing the toxic sideeffects of chemotherapy and radiotherapy. In patients with prognostically favourable factors (Table 1) [4], the number of courses of chemotherapy can be reduced, whereas in patients with prognostically unfavourable factors, more intensive chemotherapy is necessary to improve the chances of survival. Nowadays the majority of TGCT patients can be cured by multidisciplinary treatment. Therefore, the number of TGCT survivors will continue to increase. In principle, these TGCT survivors will be exposed to the long-term consequences of chemotherapy-related toxicity (side-effects) or the long-term side-effects of radiotherapy. TGCT survivors are mostly young men who can be expected to have a long life ahead of them. This has meant that over the past few years, scientific research has centred on studying the long-term effects of treatment [5-8] and the quality of life of these TGCT survivors [9]. All this research has the ultimate aim of achieving further improvement in the treatment and follow-up of TGCT patients.

\section{The somatic genetic background of TGCT}

Carcinoma in situ (CIS) (or intratubular germ cell neoplasia) is the precursor of TGCT and is found in nearly all TGCT together with an invasive component. $\mathrm{CIS}$ cells originate from primordial germ cells that "escaped" normal differentiation in utero. It is assumed that over the course of time, CIS "develops" into an invasive TGCT, but the precise transformation of premalignant CIS into a TGCT is not yet clear. It is suggested that the default pathway follows the development of CIS into seminoma and that nonseminoma requires activation of pluripotency

Table 1. IGCCCG prognostic classification for germ cell cancer [4]

\begin{tabular}{|c|c|c|}
\hline Prognosis & Non-seminoma & Seminoma \\
\hline good & $\begin{array}{l}\text { testis/retroperitoneal primary } \\
\text { and } \\
\text { no non-pulmonary visceral metastases } \\
\text { and } \\
\text { AFP }<1000 \mathrm{ng} / \mathrm{ml} \text { and } \\
\text { hCG }<1000 \mathrm{ng} / \mathrm{ml} \text { and } \\
\mathrm{LDH}<1.5 \times \mathrm{N}^{*}\end{array}$ & $\begin{array}{l}\text { any primary site } \\
\text { and } \\
\text { no non-pulmonary visceral } \\
\text { metastases } \\
\text { and } \\
\text { normal AFP, any hCG, any LDH }\end{array}$ \\
\hline intermediate & $\begin{array}{l}\text { testis/retroperitoneal primary } \\
\text { and } \\
\text { no non-pulmonary visceral metastases } \\
\text { and } \\
1000 \leq \mathrm{AFP} \leq 10000 \mathrm{ng} / \mathrm{ml} \text { or } \\
1000 \leq \mathrm{hCG} \leq 10000 \mathrm{ng} / \mathrm{ml} \text { or } \\
1.5 \times \mathrm{N} \leq \mathrm{LDH} \leq 10 \times \mathrm{N}\end{array}$ & $\begin{array}{l}\text { any primary site } \\
\text { and } \\
\text { non-pulmonary visceral } \\
\text { metastases } \\
\text { and } \\
\text { normal AFP, any hCG, any LDH }\end{array}$ \\
\hline poor & $\begin{array}{l}\text { mediastinal primary } \\
\text { or } \\
\text { non-pulmonary visceral metastases } \\
\text { or } \\
\text { AFP }>10000 \mathrm{ng} / \mathrm{ml} \text { or } \\
\text { hCG }>10000 \mathrm{ng} / \mathrm{ml} \text { or } \\
\text { LDH }>10 \times \mathrm{N}\end{array}$ & no patients classified as poor prognosis \\
\hline
\end{tabular}

${ }^{*} \mathrm{~N}$ - normal range 
(reprogramming) of a CIS or seminoma cell $[10,11]$. A theoretical model of TGCT development as part of testicular dysgenesis, taking into account a range of reported TGCT risk factors, has been developed by Skaekebaek et al. [12] and is referred to as the testicular dysgenesis syndrome (TDS) (Figure 1). In recent years several studies have looked into chromosomal abnormalities and more recently at gene mutations and gene activity in TGCT to unravel the molecular pathways underlying these tumours. A detailed overview of (non-inherited) genomic aberrations in TGCT was recently published by von Eyben [13]. Aneuploidy has been found in nearly all cases and triploidy is a common finding. Seminomas have a mean hypertriploid DNA index and nonseminomas have a mean hypotriploid DNA index (due to loss of chromosomal material during cancer progression) [11]. When looking at individual chromosomal regions, an isochromosome of the short arm of chromosome 12, i(12p), (resulting in a duplication of the short arm of chromosome 12) is found in about $80 \%$ of TGCT. The remainder have excess $12 p$ genetic material in derivative chromosomes [14]. The exact relation between these changes and TGCT is unclear but the absence of amplification of a section of $12 p$ in intratubular germ cell neoplasia suggests that this amplification may be related to progression of the disease rather than initiation [15]. A recent gene expression profile study on TGCT material identified differentiated expressed genes on $12 p$. Seventy-three genes on $12 p$ were significantly overexpressed, indicating that the $p$ arm of chromosome 12 may play an important role in TGCT tumorigenesis [16]. In addition to the genes located on $12 p$, a growing list of genes is implicated in the various stages of TGCT development. In particular, TGCT has been shown to be associated with a characteristic series of abnormalities in the retinoblastoma pathway including upregulation of cyclin D2 and p27 and downregulation of RB1 and the cyclin-dependent kinase inhibitors of p16, p18, p19 and p21 [13]. A gain of activity of the KIT gene, a member of the tyrosine kinase family, appears to play a role in the progression of CIS towards seminomas [17]. Recently, the scope of genetic study of TGCT has been extended to include the role of naturally occurring micro RNAs (miRNAs). Indeed, some of these miRNAs (miRNA-372 and 373) were shown to allow tumorigenic growth. As they have also been observed to be expressed in human seminomas and non-

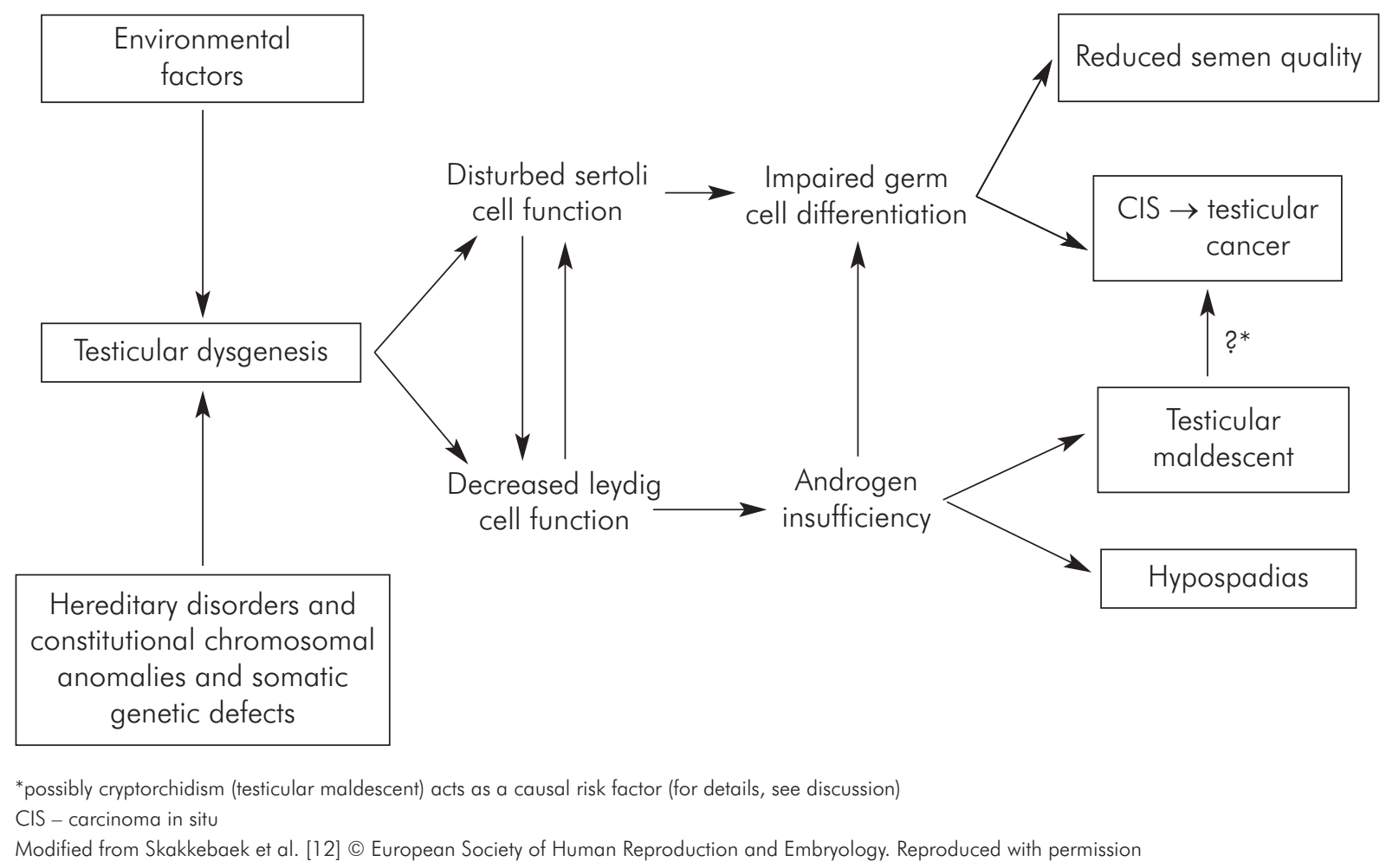

Figure 1. The testicular dysgenesis syndrome 
seminomas, but not in normal testicular tissue, it has been suggested that these miRNAs may represent a new class of oncogenes involved in TGCT [18].

\section{Histology}

TGCT can be divided into two important histological subtypes: seminoma and non-seminoma. Pure seminoma occurs in about $50 \%$ of cases and often (in 20\%) contains trophoblastic giant cells that can produce beta-human chorionic gonadotrophin $(\beta$-HCG). Non-seminoma chiefly comprises two or more cell types, for example embryonal carcinoma, choriocarcinoma (also contains trophoblastic giant cells), yolk sac tumour, and teratoma, whether or not in combination with seminoma. Embryonal carcinoma and yolk sac tumour elements are associated with the production of alpha-fetoprotein (AFP). Clinically, there are three important tumour markers in the diagnosis and follow-up of TGCT: $\beta$-HCG, $\alpha$-fetoprotein (AFP) and lactate dehydrogenase (LDH) [2].

\section{Clinical presentation and initial therapy}

Patients who present with a painless swelling of the testicle and increased levels of AFP, $\beta$-HCG and/or LDH have a TGCT until proven otherwise. Clinical presentation varies widely. TGCT can also show extratesticular clinical manifestation (without any testicular complaints). Retroperitoneal lymph node metastases can cause (lower) back pain, while haemoptysis can be the result of pulmonary metastases. Ultrasound examination of the testicle is useful to establish possible testicular abnormalities. Radical inguinal orchidectomy with high ligation of the spermatic cord, blood vessels and lymph vessels is the surgical treatment for patients who are suspected of having a TGCT. Originally, the testicles descend via the retroperitoneal route and inguinal canal into the scrotum. This often results in regional metastases from a TGCT that first arise in the retroperitoneal lymph nodes. A right-sided TGCT tends to metastasize to the interaortocaval lymph nodes, whereas a left-sided TGCT tends to metastasize to the para-aortic lymph nodes. At a higher, supradiaphragmatic level, metastases can spread via the thoracic duct and result in mediastinal or supraclavicular metastases. Haematogenically, TGCT chiefly metastasize to the lungs, later to the liver, the skeleton and the cerebrum [3, 19].

\section{Staging}

When a patient has been diagnosed with a TGCT, the malignancy must be staged. This can be done by means of tumour markers (AFP and $\beta-H C G, L D H$ ) and spiral CT (computed tomography) scanning of the lungs, the retroperitoneum and pelvis. On indication (anamnestic complaints of the cerebrum and/or sharply elevated $\beta-\mathrm{HCG}), \mathrm{CT}$ scanning of the cerebrum is conducted. The roles and/or additional value of magnetic resonance imaging (MRI) and positron emission tomography (PET) are currently under investigation [20]. At the University Medical Center Groningen, the Netherlands (UMCG), patients with TGCT are staged according to the Royal Marsden classification (Table 2). Patients with stage I have no radiological or biochemical evidence of metastases. Patients with stages II to IV have metastasized disease. These patients are subsequently classified according to the prognostic factors formulated by the International Germ Cell Cancer Collaborative Group (IGCCCG) (Table 1) and a treatment plan is drawn up on the basis of the subgroup classification (good/intermediate/poor) [4].

\section{Treatment}

\section{Stage I disease (=non-metastasized disease)}

About half of the patients with a non-seminoma present with stage I disease. Presently, the treatment comprises radical orchidectomy with high ligation of the spermatic cord, blood vessels and lymph vessels, followed by regular outpatient visits (wait-and-see policy) or modified unilateral nerve-sparing retroperitoneal lymph node dissection. The UMCG has been applying the wait-and-see policy to patients with stage I disease since 1982 [21]. In the meantime, world-wide consensus has been reached about the treatment for stage I non-seminoma patients in the low-risk group (i.e. histological examination does not show any vascular invasion of the tumour). These patients have a $15 \%$ risk of TGCT relapse; thus the wait-and-see policy is justified and comprises regular outpatient visits for 5 years after orchidectomy with physical examination, tumour marker analysis and frequent radiological investigation.

There is a great deal of discussion about the current treatment policy for patients with stage I non-seminoma in the high-risk group (i.e. histopathological investigation shows vascular invasion). Unilateral nervesparing retroperitoneal lymph node dissection (RPLND) or adjuvant chemotherapy leads to a considerable reduction in the risk of relapse of about $5 \%$. However, the disadvantages of RPLND (loss of ejaculatory function) or chemotherapy (toxicity) must be taken into consideration. The UMCG still applies the wait-andsee policy to these high-risk patients. In the UK and many other European countries, the preferred 
Table 2. Royal Marsden staging classification of testicular germ cell tumours

\begin{tabular}{|c|c|}
\hline Stage & Criteria \\
\hline । & no evidence of metastases \\
\hline IM & no clinical evidence of metastases, but persistent elevation of serum tumour markers AFP and/or hCG \\
\hline II & infradiaphragmatic lymph node metastases \\
\hline$\| A$ & metastases $<2 \mathrm{~cm}$ in diameter \\
\hline$\| B$ & metastases $2-5 \mathrm{~cm}$ in diameter \\
\hline$\| C$ & metastases $>5 \mathrm{~cm}$ in diameter \\
\hline III & supradiaphragmatic lymph node metastases; status A, B, C as for stage II \\
\hline IV & extra lymphatic metastases \\
\hline L1 & $\leq 3$ lung metastases \\
\hline $\mathrm{L} 2$ & $>3$ lung metastases, all $\leq 2 \mathrm{~cm}$ in diameter \\
\hline L3 & $>3$ lung metastases, one or more $>2 \mathrm{~cm}$ in diameter \\
\hline $\mathrm{H}+, \mathrm{Br}+, \mathrm{Bo}+$ & liver, brain, or bone metastases \\
\hline
\end{tabular}

approach for high-risk patients is often to administer two courses of adjuvant chemotherapy, whereas in the USA it is the trend to perform nerve-sparing unilateral RPLND [2, 3]. Which treatment policy is the best for these so-called 'high-risk' patients is unknown.

About $75 \%$ of patients with seminoma have stage I disease. The standard treatment after orchidectomy is radiotherapy of the retroperitoneal para-aortic lymph nodes with a total dose of 20 Gy. In this way the relapse rate is reduced to 1-3\% [2]. The advantage of para-aortic radiotherapy (while excluding the ipsilateral lymph nodes) is less gastrointestinal and gonadal toxicity. As an alternative to radiotherapy, adjuvant chemotherapy can be administered. The latter approach results in the same relapse rates [22]. A waitand-see policy alone would lead to relapse rates of 15 to $20 \%$ and is less suitable, because there are no sensitive tumour markers for seminoma and the patient would therefore have to undergo frequent radiological investigation $[2,3]$.

\section{Metastasized disease}

Patients with stage $\mathrm{Ila}$ and $\mathrm{Ilb}$ seminoma receive radiotherapy with a total dose of 30 and $36 \mathrm{~Gy}$, respectively. In contrast to stage I seminoma, the ipsilateral iliac lymph nodes are also included in the treatment volume (dog-leg field) in patients with stage II seminoma. This approach achieves 6-year relapse- free survival of $95 \%$ in stage lla patients and $89 \%$ in stage Ilb patients. Alternative treatments to radiotherapy can be considered in stage Ilb patients, for example 3 courses of BEP (bleomycin, etoposide and cisplatin) or 4 courses of EP (etoposide and cisplatin) [2, 3].

Treatment for patients with stage IIc-IV metastasized seminoma and with stage II-IV metastasized nonseminoma comprises chemotherapy in accordance with the prognostic factor classification. In the good prognosis group, patients with non-seminoma/ seminoma receive chemotherapy in the form of 3 courses of BEP or 4 courses of EP. Patients in the intermediate and poor prognosis groups are treated with 4 courses of BEP $[2,23,24]$.

\section{Surgery after chemotherapy}

After completion of chemotherapy, patients with a metastasized tumour (TGCT) at the UMCG undergo restaging with the aid of serum tumour marker analyses (as described above) and spiral CT scanning of the lungs and retroperitoneum. When radiological investigation shows residual disease after completion of chemotherapy in patients with seminoma, surgical resection is not performed, but instead the abnormality is followed radiologically. Generally, a new indication will arise for chemotherapy or radiotherapy, which if necessary is combined with surgical resection of the residual tumour. Presently, positron emission 
tomography (PET) scanning can be applied to help identify viable cancer [25].

After patients with non-seminomatous TGCT have completed chemotherapy, there is no indication for surgical resection when they do not show any residual disease, or the residual abnormality is smaller than $1 \mathrm{~cm}$, the tumour markers have normalised and mature teratoma is absent from the primary tumour. Followup is then conducted on the basis of tumour markers. However, when residual (abdominal/pulmonary) disease is identified, surgical resection must be performed on the residual retroperitoneal tumour mass (RRRTM), or local resection in the case of residual pulmonary tumour tissue. When residual tumour persists after completion of chemotherapy and the tumour markers remain high, an individual treatment plan must be drawn up: salvage chemotherapy or salvage surgery.

In patients with non-seminomatous TGCT, it is not possible to predict the histology of the residual tumour. After surgical resection, histological examination shows that the mass consists of necrosis in $45 \%$ of cases, mature teratoma in $40 \%$, viable tumour tissue in $10 \%$ and nongerm cell malignancies in the remaining 5\% [26].

When the resected residual tumour only contains necrosis or mature teratoma, no further treatment is necessary and the patient has an excellent prognosis. However, when viable tumour tissue is present, the prognosis is less favourable and depending on factors such as the initial prognostic classification (Table 1), the volume (percentage) of residual viable cancer and the completeness of the resection, it may be necessary to administer adjuvant salvage chemotherapy [27].

The clinical significance of mature teratoma in the residual tumour is not yet completely clear and it is impossible to predict the course that can be expected from mature teratoma left in situ. In the literature, "growing teratoma" is a well-known phenomenon and it can lead to (very) late tumour recurrence. In addition, there is a risk that mature teratoma will de-differentiate into a non-germ cell malignancy (e.g. sarcoma). In such cases, the prognosis of the patient is far less favourable. Radical surgery is the only curative treatment option for these non-germ cell tumours.

When the primary TGCT contains elements of mature teratoma, there is a greater chance that the residual tumour will also contain teratomatous elements. Therefore, at the UMCG, all patients with elements of teratoma in the primary tumour undergo laparotomy and partial retroperitoneal dissection at the "original" tumour site after chemotherapy, even when there are no radiological signs of residual disease [26].

\section{Familial, hereditary and syndromic aspects}

\section{Family history}

$1-3 \%$ of patients with TGCT report an affected firstdegree relative, a proportion higher than would be expected by chance [28-38]. The largest number of reported cases in a family is five [39], but most familial clustering consists of relative pairs such as two affected brothers and to a smaller extent an affected father and son $[30,40]$. Brothers of patients with TGCT have a relative risk of TGCT of 8-10, and for father-son the relative risk is $4-6[30,31,36]$.

\section{Racial differences and geographical clustering}

Geographical clustering of TGCT [41] and racial differences in the incidence of this disease could indicate a genetic component in the cause of the disease. The highest incidence is seen in white people of northern European descent, whereas people of African or Asian descent seem to have a universally low incidence of TGCT [40, 42-44]. Observed differences in incidence persisting after migration argue in favour of genetic rather than exogenous risk factors.

\section{Bilateral TGCT}

Heimdal and co-workers [31] found that 2.8\% of patients with TGCT who did not have a family history had bilateral disease compared with $9.8 \%$ of those with a positive family history. Somatic mutations of the KIT oncogene occur in a very high proportion (95\%) of tumours from patients with bilateral disease compared with a smaller proportion (3\%) of tumours from those with unilateral disease [45]. When both tumours from bilateral cases could be assessed, an identical KIT mutation was observed. Patients with a family history of TGCT had a similar frequency of KIT mutations in unilateral TGCT compared with sporadic cases. Interestingly, in patients with bilateral disease and a family history of TGCT only $28 \%$ of tumours showed KIT mutations, suggesting that bilateral disease in the context of familial TGCT has a different pathogenesis from sporadic bilateral cases [46].

\section{Cryptorchism and other disorders of testicular differentiation in patients and relatives}

Cryptorchism and other testicular abnormalities such as atropy, infertility, hydrocele and inguinal hernia are risk factors for TGCT [47-50]. Forman and co- 
workers [30] showed that the frequency of cryptorchism in patients with TGCT did not differ between those with or without a positive family history. From a different perspective, Tollerud and colleagues [37] showed that cryptorchism or inguinal hernia occurred in a significantly greater proportion of first-degree male relatives of patients with a family history of TGCT than of relatives of patients with sporadic TGCT or of controls. The high prevalence of cryptorchism, inguinal hernias, and hydrocele in these families suggests that an underlying shared genetic defect might be present. Up to approximately $8 \%$ of infertility in the general male population can be explained by the presence of constitutional deletions of part of the long arm of the $Y$ chromosome ( $Y q 11$ ), referred to as the azoospermia factor (AZF) region (subdivided into AZFa to AZFd) [5153]. AZFc deletions are the most commonly found (60\%). Although most of the AZF deletions observed in infertile men are new (de novo) mutations, they have been inherited in some cases from (apparently fertile) fathers, and $0.4 \%$ of fertile men in the general population appear to carry an AZF deletion [52]. Foresta et al. recently observed a particularly high percentage of $27.5 \% \mathrm{AZF}$ (a-c) deletions in patients with low sperm counts as well as unilateral cryptorchism [54]. Cryptorchism is an acknowledged risk factor for TGCT and is one of the postulated other possible manifestations of TDS. Taken together, these observations suggests that, at least from a theoretical point of view, constitutional AZF deletions might be one of the genetic contributors to the development of TDS and thereby of TGCT and other TDS manifestations. We investigated the frequency of $Y$ chromosome deletions in the AZF region, in a series of fertile, as well as infertile, patients with TGCT, but did not find any deletions [55]. However, more recently a novel Y-chromosome 1.6-MB deletion was reported, referred to as $\mathrm{gr} / \mathrm{gr}$, and is associated with spermatogenic failure [56]. This deletion is much smaller than the deleted AZF region studied previously and removes only part of the AZFc region, including copies of DAZ and a copy of CDY 1, as well as other transcription units. Nathason et al. recently described an association between $\mathrm{gr} / \mathrm{gr}$ deletions and TGCT. Familial TGCT patients had a threefold increased risk of having these $\mathrm{gr} / \mathrm{gr}$ deletions [57].

\section{Risk of other tumours in relatives of TGCT patients}

Many studies $[38,58]$ confirm a high incidence of TGCT in relatives of patients with TGCT. In contrast, there appears to be no excess risk of other cancer types in first-degree relatives of patients with TGCT, with the exception of patients' mothers, who have are at an increased risk of developing lung cancer, nonendometrial uterine cancer, soft tissue tumours and melanoma [29].

\section{Syndromic aspects}

Patients with Klinefelter's syndrome (47 XXY) have a very high risk of mediastinal, (extragonadal) germcell tumours, and some may also be at risk of developing TGCT [59]. About $8 \%$ of patients with such tumours have Klinefelter's syndrome [60]. Patients with $X Y$, or $45, X / 46, X Y$ gonadal dysgenesis have a greatly increased risk of germ-cell tumours [59, 61]. Patients with Down's syndrome (trisomy 21) might also be at increased risk of TGCT but the numbers are too small for firm conclusions to be drawn $[62,63]$. The presence of TGCT in a hereditary syndrome might be an indication of a hereditary predisposition to TGCT. Owing to the rarity of most of these disorders and the scarce reports of their occurrence in combination with TGCT, there is no statistical proof of an association of TGCT with these disorders. However, as our literature survey demonstrated [64], it is striking that in a subset of these disorders there is also a range of defects in urogenital differentiation, which suggests that TGCT in these disorders is indeed a further complication of such a differentiation defect, as postulated in the TDS model of Skakkebaek and colleagues (Figure 1) [12].

\section{Twin studies}

Swerdlow and colleagues [65] found that the risk of TGCT was raised in twin brothers of patients with TGCT (relative risk 37.5, 95\% Cl 12.3-1 15.6) and was greater in monozygotic (76.5) than dizygotic (35.7) twins. This relative risk is several times that found in non-twin brothers (although the confidence limits are wide due to the small numbers) but it does imply that the genetic element for risk is far larger for TGCT than for most other cancers. Other twin studies on TGCT have not had sufficient numbers of concordant twin pairs and could not confirm this result. Several studies have confirmed a higher frequency of TGCT in dizygotic twins than in singletons and monozygotic twins. It has been postulated that abnormally high oestrogen concentrations in pregnancy predispose the developing gonad to TGCT in adulthood [66]. Interestingly, the concentration of circulating oestrogen is significantly higher in pregnancies with dizygotic than in those with monozygotic twins or singletons, and therefore might have been a contributory causative factor $[65,67,68]$. 


\section{Modelling studies}

Two studies so far have tried to identify the mode of inheritance of TGCT susceptibility genes. One was based on the frequency of bilateral TGCT [69], and the other was a segregation analysis on a group of Norwegian and Swedish families [70]. The latter study reported that the familial clustering was best accounted for by a major gene for TGCT with a recessive mode of inheritance. Under this recessive model, $7.3 \%$ of men in the population carry the mutant allele and $0.1 \%$ are homozygous. According to the calculations by the authors, the lifetime risk of development of TGCT in homozygous men is 43\% [70]. Based on a comparison of the distribution of age at diagnosis between patients with bilateral TGCT and familial cases (i.e. those likely to be genetically determined), Nicholson and Harland [69] assumed in their model that the increased risk was due solely to genetic susceptibility. These authors estimated that about a third of general patients with TGCT carry the susceptibility genotype and that the penetrance is 0.45 . Calculations with these values showed that a recessive disease model showed a better fit with the observed risks for brothers (2.2\%) and fathers $(0.5 \%)$ of patients with TGCT than a dominant disease model. The frequency of the susceptibility allele in the recessive model was estimated to be $5 \%$. The higher relative risk for brothers than for father-son pairs is compatible with contributions from a recessive mode of inheritance, but since the early 1990s the incidence of TGCT has increased sharply, maintenance of fertility after treatment for TGCT has improved greatly, and the introduction of cisplatin-based chemotherapy has substantially lowered the number of deaths from TGCT [71-73]. These changes may lead to a situation in which updated relative risk estimates for father-son pairs turn out to be higher than previous ones. In addition to a recessive model, a dominant form of inheritance as well as an X-linked one could not be excluded. Because a proportion of bilateral cases are caused by early somatic mutations in KIT and because there is likely to be more than one TGCT susceptibility gene, susceptibility to TGCT is probably more complex than suggested by either of these models.

\section{Association studies and haplotype analyses}

Previous studies have shown that HLA factors might be associated with the development of TGCT. In particular, consistent associations were found with the HLA class II antigens. No association was found with the HLA-A and HLA-C regions, and inconsistent associations were found with the HLA-B region [74].
The first HLA genotyping study by Özdemir and colleagues [75] in 55 Japanese patients showed two associations: one HLA susceptibility allele and one HLA protective allele (relative risk 3.26 and 0.26 respectively). Our own, larger, genotyping study on the HLA class II region of chromosome 6p21 on 151 patients from the northern part of the Netherlands could not replicate this association [74]. The association between TGCT and HLA class II alleles either does not exist, or is much weaker than the earlier report suggested. To date, no convincing associations have been shown between TGCT and a genetic polymorphism.

\section{Linkage analysis and genome-wide screens}

The International Testicular Cancer Linkage Consortium (ITCLC) has the largest collection of TGCT pedigrees with two or more cases of TGCT in a family. Their first evidence for a TGCT susceptibility gene was for the X chromosome [76]. The analysis on 99 pedigrees compatible with $X$ linkage (no male-to-male transmission) yielded a heterogeneity LOD score of 2.01 on chromosome $\mathrm{Xq} 27$. Families with at least one case of bilateral disease showed strong evidence of linkage to a locus on Xq27 (heterogeneity LOD score $=4.76$ ) and were more likely to show linkage to the $X$ chromosome than families without a bilateral case. This proposed susceptibility gene on chromosome Xq27 was referred to as TGCT1 [76]. The ITCLC reported preliminary results on an additional 25 pedigrees compatible with $X$ linkage but the set was too small for any firm conclusions to be drawn [77]. In our own study we did not find an association between Xq27 and familial TGCT, cryptorchism or bilateral TGCT [78]. Interestingly, we did observe an association between the subset of TGCT cases without a family history of TGCT or cryptorchism and specific alleles for the marker DXS1193 both by allelic association analysis and by the haplotype sharing statistics. The frequency of all minor alleles was increased among these patients compared to controls: 13.9 vs. 3.4\%, respectively. The risk of developing sporadic TGCT without cryptorchism for an individual who has one of the minor alleles was estimated to be 4.7 (99.57\% Cl: 1.1-19.6). This suggests that in our Dutch population one or more low frequent mutations of an Xq27-linked gene contribute to TGCT development but not to cryptorchism. Alternatively, particular genotypes in this region possibly protect the normal population from developing TGCT. Further analyses on single nucleotide polymorphism (SNPs) in candidate genes in this region should be performed 
to identify the causal gene and to unravel the nature of its causality. With respect to autosomal loci, the latest ITCLC study reported on a genome-wide screen in a total of 179 pedigrees and failed to detect any LOD scores greater than 3 in any autosomal locus. Suggestive evidence for linkage has been obtained for several autosomal regions including 3q27, 12q12-q13, 16p13, and 18q22-qter [77]. The power to detect some or all of the susceptibility genes for TGCT will depend greatly on the degree of genetic heterogeneity of this disease. Continued identification and recruitment of families into this linkage study will be crucial to the efforts to identify these genes.

\section{Discussion and future perspectives}

The incidence of TGCT has doubled over the last 40 years. This increase is unlikely to be caused by genetic predisposition alone and environmental factors most likely play an important role as well. Although TGCT is an infrequent disease and it is highly curable, it is still important to unravel the environmental risk factors as well as genetic predisposition for TGCT. Early identification of men with increased risk for inherited TGCT might lead to early detection and improved treatment outcome. In the current literature there are no data on the clinical behaviour (or prognosis) of TGCT in patients with familial TGCT. However, clinical observation does not suggest any differences in survival and presently there is no reason to expect that familial TGCT has a different outcome than sporadic TGCT. Thus identifying TGCT in genetically predisposed men at an earlier stage is expected to improve survival similar to sporadic cases. Early detection could theoretically be achieved by ultrasound of the testes, palpation (routine testicular self examination) and/or by measuring tumour markers. Presently, however, there is no proof that men who routinely examine their testes are more likely to detect earlier stage tumours or improve their prospects for survival [79] and there are no data on possible benefits of clinical surveillance in familial TGCT. Treatment of TGCT may be further optimized using new insights in the oncogenetic pathways involved, possibly reducing the need for toxic chemotherapy and radiotherapy. The unravelling of the genetic pathway of TGCT might result in the opportunity to develop gene therapy. There are some trials in other types of cancer with promising results. The use of genetically modified autologous tumour cells appears to be a valuable approach for cancer therapy. Further studies are required to determine whether effects on immune activation will result in actual clinical benefit for patients [80].
Although circumstantial evidence points to the existence of TGCT predisposition, no germ line gene mutations have yet been identified that confer a high risk of developing TGCT. The question arises whether such mutations exist at all or whether genetic predisposition to TGCT will turn out (as the $\mathrm{gr} / \mathrm{gr}$ deletions did) to consist of a range of mutations, each with only relatively weak effects. One barrier to resolving this issue is the fact that large families with a strong family history of TGCT are rare. The ITCLC, which has done an impressive job of collecting a series of 459 pedigrees, has not been able to firmly identify genomic regions associated with high TGCT risk so far and suggests that susceptibility to TGCT might be determined through multiple loci as opposed to a single locus. Possibly, very strongly inherited TGCT predisposition does not exist. Unfortunately, linkage analysis, in contrast to association studies, is not a powerful tool for gene detection when mildly predisposing frequent genetic variants play a role [81]. With 459 pedigrees, of which the ITCLC examined only 237, because the rest were considered not well sampled, only a relative risk of 5 or larger for carriers of a genetic variant (frequency of $15 \%$ ) can be detected. To detect a relative risk of 2, which is realistic in complex human diseases, one would need to study at least 2000 pedigrees to have $80 \%$ power to detect such a genetic variant. On the other hand, it cannot be excluded that (part of) the familial clusters can still be attributed to different, rare, strongly predisposing gene mutations present in subsets of families, that, because of their low frequency in the population, may very well escape detection in such relatively small linkage studies. It may be interesting to perform linkage studies in a subset of familial TGCT patients with urogenital malformations (such as hypospadia, cryptorchism, bilateral disease), because in this subgroup of patients (identical phenotypes) it is very possible that they share a causative gene which results in urogenital malformations as well as TGCT (Skakkebaek model).

Recently the genetic defect in mouse strain 129.MOLF-Chr19 chromosome substitution strain, known to develop TGCTs at a high frequency (70-80\%), was reported [82]. A germ line mutation in the dead end gene (DND1) was found to cause this high tumour risk (and some testicular and spermatogenic abnormalities) [57]. Very little is known about the human homologue of DND1 and it is therefore worthwhile to study its possible association with human TGCT.

The collection of more families with TGCT will facilitate genetic studies. Some hospitals systematically collect DNA from their cancer patients in a prospective 
way in order to expand the material for genetic studies. The Icelandic deCODE initiative (www.decode.com) takes this approach a large step further by linking genealogical data with disease status and DNA markers in their national population. Such approaches are to be encouraged from a purely scientific point of view; however, privacy and other ethical and legal issues involved in these approaches need to be addressed very thoroughly. International collaboration will be facilitated if DNA and patient data collecting are performed according to (to be developed) international standards. The HapMap project, a partnership of scientists and funding agencies all over the world to develop a public resource that will help researchers find genes associated with human disease, is a good example (www.hapmap.org).

Not only are study populations expanding through collaborative efforts; statistical techniques and insights into cancer biology and its resulting molecular tools are evolving as well. Recently, the scope of genetic study of TGCT has been extended to include the role of naturally occurring micro RNAs (miRNAs). Normally miRNAs function as regulators of genetic pathways by manipulating translational regulation. Some of these miRNAs (miRNA-372 and 373) were shown to allow tumorigenic growth. As they have also been observed to be expressed in human seminomas and nonseminomas, but not in normal testicular tissue, it has been suggested that these miRNAs may represent a new class of oncogenes involved in TGCT development [18]. Time will tell whether miRNAs play a role in (testicular) cancer predisposition.

Should future studies identify clinically important TGCT-predisposing mutations, then testing for these mutations might be welcomed by a substantial subset of TGCT patients and families, as has been the case for many families with common hereditary tumour syndromes. Research on early detection techniques for TGCT in high-risk men will be necessary. Although many studies have looked into the psychosocial aspects and requirements for genetic testing programmes in these syndromes, very little is known with respect to testing in the setting of TGCT. Research on early detection techniques for TGCT in high-risk men will be necessary. As in any other new genetic testing programme, testing would need to be performed in a research setting first, where medical as well as psychosocial issues would need to be carefully monitored.

\section{References}

1. Cancer in the Netherlands, trends, prognoses and implications for call of health. www.kwfkankerbestrijding.nl/content /documents/SCK_rapport_Kanker_in_Nederland.pdf 2004.
2. Albers P, Albrecht W, Algaba F, Bokemeyer C, Cohn-Cedermark G, Horwich A, Klepp O, Laguna MP, Pizzocaro G. Guidelines on testicular cancer. Eur Urol 2005; 48: 885-894.

3. Schmoll HJ, Souchon R, Krege S, Albers P, Beyer J, Kollmannsberger C, Fossa SD, Skakkebaek NE, de Wit R, Fizazi K, Droz JP, Pizzocaro G, Daugaard G, de Mulder PH, Horwich A, Oliver T, Huddart R, Rosti G, et al. European consensus on diagnosis and treatment of germ cell cancer: a report of the European Germ Cell Cancer Consensus Group (EGCCCG). Ann Oncol 2004; 15: 1377-1399.

4. International Germ Cell Consensus Classification: a prognostic factor-based staging system for metastatic germ cell cancers. International Germ Cell Cancer Collaborative Group. J Clin Oncol 1997; 15: 594-603.

5. Abouassaly R, Klein EA, Raghavan D. Complications of surgery and chemotherapy for testicular cancer. Uro Oncol 2005; 23: 447-455.

6. Meinardi MT, Gietema JA, van der Graaf WT, van Veldhuisen DJ, Runne MA, Sluiter WJ, de Vries EG, Willemse PB, Mulder $\mathrm{NH}$, van den Berg MP, Koops HS, Sleijfer DT. Cardiovascular morbidity in long-term survivors of metastatic testicular cancer. J Clin Oncol 2000; 18: 1725-1732.

7. Nuver J, Smit AJ, Wolffenbuttel BH, Sluiter WJ, Hoekstra HJ, Sleijfer DT, Gietema JA. The metabolic syndrome and disturbances in hormone levels in long-term survivors of disseminated testicular cancer. J Clin Oncol 2005; 23: 3718 3725.

8. Nuver J, Smit AJ, Sleijfer DT, van Gessel Al, van Roon AM, van der Meer J, van den Berg MP, Hoekstra HJ, Sluiter WJ, Gietema JA. Left ventricular and cardiac autonomic function in survivors of testicular cancer. Eur J Clin Invet 2005; 35: 99-103.

9. Fleer J. Quality of life of testicular cancer survivors. Thesis: http://irs.ub.rug.nl/ppn/291569412. University of Groningen, The Netherlands 2006.

10. Hoei-Hansen CE, Rajpert-De Meyts E, Daugaard G, Skakkebaek NE. Carcinoma in situ testis, the progenitor of testicular germ cell tumours: a clinical review. Ann Oncol 2005; 16: 863-868.

11. Oosterhuis JW, Looijenga LH. Testicular germ-cell tumours in a broader perspective. Nat Rev Cancer 2005; 5: 210-222.

12. Skakkebaek NE, Rajpert-De Meyts E, Main KM. Testicular dysgenesis syndrome: an increasingly common developmental disorder with environmental aspects. Hum Reprod 2001; 16 : 972-978.

13. von Eyben FE. Chromosomes, genes, and development of testicular germ cell tumors. Cancer Genet Cytogenet 2004; 151: 93-138.

14. Reuter VE. Origins and molecular biology of testicular germ cell tumors. Mod Pathol 2005; 18 (Suppl 2): S51-S60.

15. Dearnaley D, Huddart R, Horwich A. Regular review: Managing testicular cancer. Br Med J 2001; 322: 1583-1588.

16. Korkola JE, Houldsworth J, Chadalavada RS, Olshen AB, Dobrzynski D, Reuter VE, Bosl GJ, Chaganti RS. Down-regulation of stem cell genes, including those in a $200-\mathrm{kb}$ gene cluster at 12 p13.31, is associated with in vivo differentiation of human male germ cell tumors. Cancer Res 2006; 66: 820-827.

17. Mclntyre A, Summersgill B, Grygalewicz B, Gillis AJ, Stoop J, van Gurp RJ, Dennis N, Fisher C, Huddart R, Cooper C, Clark J, Oosterhuis JW, Looijenga LH, Shipley J. Amplification and overexpression of the KIT gene is associated with progression in the seminoma subtype of testicular germ cell tumors of adolescents and adults. Cancer Res 2005; 65: 8085-8089.

18. Voorhoeve PM, le Sage C, Schrier M, Gillis AJ, Stoop H, Nagel R, Liu YP, van Duijse J, Drost J, Griekspoor A, Zlotorynski E, Yabuta N, De Vita G, Nojima H, Looijenga LH, 
Agami R. A genetic screen implicates miRNA-372 and miRNA373 as oncogenes in testicular germ cell tumors. Cell 2006; 124: 1169-1181.

19. van Basten JP, Schrafford Koops H, Sleijfer DT, Pras E, van Driel MF, Hoekstra HJ. Current concepts about testicular cancer. Eur J Surg Oncol 1997; 23: 354-360.

20. Hain SF, O'Doherty MJ, Timothy AR, Leslie MD, Partridge SE, Huddart RA. Fluorodeoxyglucose PET in the initial staging of germ cell tumours. Eur J Nucl Med 2000; 27: 590-594.

21. Gels ME, Hoekstra HJ, Sleijfer DT, Marrink J, de Bruijn HW, Molenaar WM, Freling NJ, Droste JH, Schraffordt KH. Detection of recurrence in patients with clinical stage I nonseminomatous testicular germ cell tumors and consequences for further followup: a single-center 10-year experience. J Clin Oncol 1995; 13 $1188-1194$.

22. Oliver RT, Mason MD, Mead GM, von der Maase H, Rustin GJ, Joffe JK, de Wit R, Aass N, Graham JD, Coleman R, Kirk SJ, Stenning SP. Radiotherapy versus single-dose carboplatin in adjuvant treatment of stage I seminoma: a randomised trial. Lancet 2005; 366: 293-300.

23. de Wit R, Stoter G. Treatment of metastatic testicular carcinoma according to prognosis; new development. Ned Tijdschr Geneeskd 2001; 145: 1194-1199.

24. de Wit R, Roberts JT, Wilkinson PM, de Mulder PH, Mead GM, Fosså SD, Cook P, de Prijck L, Stenning S, Collette L. Equivalence of three or four cycles of bleomycin, etoposide, and cisplatin chemotherapy and of a 3- or 5-day schedule in good-prognosis germ cell cancer: a randomized study of the European Organization for Research and Treatment of Cancer Genitourinary Tract Cancer Cooperative Group and the Medical Research Council. J Clin Oncol 2001; 19: 1629-1640.

25. De Santis M, Becherer A, Bokemeyer C, Stoiber F, Oechsle K, Sellner F, Lang A, Kletter K, Dohmen BM, Dittrich C, Pont J. 2-18fluoro-deoxy-D-glucose positron emission tomography is a reliable predictor for viable tumor in postchemotherapy seminoma: an update of the prospective multicentric SEMPET trial. J Clin Oncol 2004; 22: 1034-1039.

26. Lutke Holzik MF, Hoekstra HJ, Mulder NH, Suurmeijer AJ, Sleiifer DT, Gietema JA. Non-germ cell malignancy in residual or recurrent mass after chemotherapy for nonseminomatous testicular germ cell tumor. Ann Surg Oncol 2003; 10: 131-135.

27. Fizazi K, Tjulandin S, Salvioni R, Germa-Lluch JR, Bouzy J, Ragan D, Bokemeyer C, Gerl A, Flechon A, de Bono JS, Stenning S, Horwich A, Pont J, Albers P, De Giorgi U, Bower M, Bulanov A, Pizzocaro $G$, et al. Viable malignant cells after primary chemotherapy for disseminated nonseminomatous germ cell tumors: prognostic factors and role of postsurgery chemotherapy - results from an international study group. J Clin Oncol 2001; 19: 2647-2657.

28. Dieckmann KP, Pichlmeier U. The prevalence of familial testicular cancer: an analysis of two patient populations and a review of the literature. Cancer 1997; 80: 1954-1960.

29. Dong C, Lönnstedt I, Hemminki K. Familial testicular cancer and second primary cancers in testicular cancer patients by histological type. Eur J Cancer 2001; 37: 1878-1885.

30. Forman D, Oliver RT, Brett AR, Marsh SG, Moses JH, Bodmer JG, Chilvers CE, Pike MC. Familial testicular cancer: a report of the UK family register, estimation of risk and an HLA class 1 sib-pair analysis. Br J Cancer 1992; 65: 255-262.

31. Heimdal K, Olsson H, Tretli S, Flodgren P, Børresen AL, Fossa SD. Familial testicular cancer in Norway and southern Sweden. Br J Cancer 1996; 73: 964-969.

32. Kruse $C$. Bilateral and familial occurrence of germ cell tumors of the testis. Urologe A 1987; 26: 61-62.
33. Ondrus D, Kuba D, Chrenová S, Matoska J. Familial testicular cancer and developmental anomalies. Neoplasma 1997; 44: 59-61.

34. Patel SR, Kvols LK, Richardson RL. Familial testicular cancer: report of six cases and review of the literature. Mayo Clin Proc 1990; 65: 804-808.

35. Polednak AP. Familial testicular cancer in a population-based cancer registry. Urol Int 1996; 56: 238-240.

36. Sonneveld DJ, Sleijfer DT, Schraffordt Koops H, Sijmons RH, van der Graaf WT, Sluiter WJ, Hoekstra HJ. Familial testicular cancer in a single-centre population. Eur J Cancer 1999; 35: 13681373.

37. Tollerud DJ, Blattner WA, Fraser MC, Brown LM, Pottern L, Shapiro E, Kirkemo A, Shawker TH, Javadpour N, O'Connell K, et al. Familial testicular cancer and urogenital developmental anomalies. Cancer 1985; 55: 1849-1854.

38. Westergaard T, Olsen JH, Frisch M, Kroman N, Nielsen JW, Melbye M. Cancer risk in fathers and brothers of testicular cancer patients in Denmark. A population-based study. Int J Cancer 1996; 66: 627-631.

39. Goss PE, Bulbul MA. Familial testicular cancer in five members of a cancer-prone kindred. Cancer 1990; 66: 2044-2046.

40. Forman D, Gallagher R, Møller H, Swerdlow TJ. Aetiology and epidemiology of testicular cancer: report of consensus group. Prog Clin Biol Res 1990; 357: 245-253.

41. Sonneveld DJ, Schaapveld M, Sleiifer DT, te Meerman GJ, van der Graaf WT, Sijmons RH, Schraffordt Koops H, Hoekstra HJ. Geographic clustering of testicular cancer incidence in the northern part of The Netherlands. Br J Cancer 1999; 81: 12621267.

42. Bosl GJ, Motzer RJ. Testicular germ-cell cancer. N Engl J Med 1997; 337: 242-253.

43. Heimdal K, Fosså SD. Genetic factors in malignant germ-cell tumors. World J Urol 1994; 12: 178-181.

44. Senturia YD. The epidemiology of testicular cancer. Br J Urol 1987; 60: 285-291.

45. Looijenga LH, de Leeuw $H$, van Oorschot $M$, van Gurp RJ, Stoop H, Gillis AJ, de Gouveia Brazao CA, Weber RF, Kirkels WJ, van Dijk T, von Lindern M, Valk P, Lajos G, Olah E, Nesland JM, Fosså SD, Oosterhuis JW. Stem cell factor receptor (c-KIT) codon 816 mutations predict development of bilateral testicular germ-cell tumors. Cancer Res 2003; 63: 7674-7678.

46. Rapley EA, Hockley S, Warren W, Johnson L, Huddart R, Crockford G, Forman D, Leahy MG, Oliver DT, Tucker K, Friedlander M, Phillips KA, Hogg D, Jewett MA, Lohynska R, Daugaard G, Richard S, Heidenreich A, Geczi L, Bodrogi I, Olah E, Ormiston WJ, Daly PA, Looijenga LH, Guilford P, Aass N, Fosså SD, Heimdal K, Tjulandin SA, Liubchenko L, Stoll H, Weber W, inhorn L, Weber BL, McMaster M, Greene MH, Bishop DT, Easton D, Stratton MR. Somatic mutations of KIT in familial testicular germ cell tumours. Br J Cancer 2004; 90: 2397-2401.

47. Aetiology of testicular cancer: association with congenital abnormalities, age at puberty, infertility, and exercise. United Kingdom Testicular Cancer Study Group. BMJ 1994; 308: 1393-1399.

48. Gallagher RP, Huchcroft S, Phillips N, Hill GB, Coldman AJ, Coppin C, Lee T. Physical activity, medical history, and risk of testicular cancer (Alberta and British Columbia, Canada). Cancer Causes Control 1995; 6: 398-406.

49. Harland SJ, Cook PA, Fossa SD, Horwich A, Mead GM, Parkinson MC, Roberts JT, Stenning SP. Intratubular germ cell neoplasia of the contralateral testis in testicular cancer: defining a high risk group. J Urol 1998; 160: 1353-1357. 
50. Jacobsen R, Bostofte E, Engholm G, Hansen J, Olsen JH, Skakkebaek NE, Moller H. Risk of testicular cancer in men with abnormal semen characteristics: cohort study. BMJ 2000; 321: 789-792.

51. Kent-First M, Muallem A, Shultz J, Pryor J, Roberts K, Nolten W, Meisner L, Chandley A, Gouchy G, Jorgensen L, Havighurst T, Grosch J. Defining regions of the Y-chromosome responsible for male infertility and identification of a fourth AZF region (AZFd) by Y-chromosome microdeletion detection. Mol Reprod Dev 1999; 53: 27-41.

52. Layman LC. Human gene mutations causing infertility. J Med Genet 2002; 39: 153-161

53. Vogt PH, Edelmann A, Kirsch $S$, Henegariu $O$, Hirschmann $P$ Kiesewetter F, Köhn FM, Schill WB, Farah S, Ramos C, Hartmann M, Hartschuh W, Meschede D, Behre HM, Castel A, Nieschlag E, Weidner W, Gröne HJ, Jung A, Engel W, Haidl G. Human Y chromosome azoospermia factors (AZF) mapped to different subregions in Yq1 1. Hum Mol Genet 1996; 5: 933-943.

54. Foresta C, Moro E, Garolla A, Onisto M, Ferlin A. $Y$ chromosome microdeletions in cryptorchidism and idiopathic infertility. J Clin Endocrinol Metab 1999; 84: 3660-3665.

55. Lutke Holzik MF, Storm K, Sijmons RH, D'hollander M, Arts EG, Verstraaten ML, Sleiifer DT, Hoekstra HJ. Absence of constitutional Y chromosome AZF deletions in patients with testicular germ cell tumors. Urology 2005; 65: 196-201.

56. Repping S, Skaletsky H, Brown L, van Daalen SK, Korver CM, Pyntikova T, Kuroda-Kawaguchi T, de Vries JW, Oates RD, Silber S, van der Veen F, Page DC, Rozen S. Polymorphism for a 1.6-Mb deletion of the human $Y$ chromosome persists through balance between recurrent mutation and haploid selection. Nat Genet 2003; 35: 247-251.

57. Nathanson KL, Kanetsky PA, Hawes R, Vaughn DJ, Letrero R, Tucker K, Friedlander M, Phillips KA, Hogg D, Jewett MA, Lohynska R, Daugaard G, Richard S, Chompret A, BonaitiPellie C, Heidenreich A, Olah E, Geczi L et al. The Y deletion $\mathrm{gr} / \mathrm{gr}$ and susceptibility to testicular germ cell tumor. Am J Hum Genet 2005; 77: 1034-1043.

58. Heimdal K, Olsson H, Tretli S, Flodgren P, Børresen AL, Fossa $\mathrm{SD}$. Risk of cancer in relatives of testicular cancer patients. $\mathrm{Br} J$ Cancer 1996; 73: 970-973.

59. Nichols CR, Heerema NA, Palmer C, Loehrer PJ Sr, Williams SD, Einhorn LH. Klinefelter's syndrome associated with mediastinal germ cell neoplasms. J Clin Oncol 1987; 5: 1290-1294.

60. Fosså SD, Aass N, Heilo A, Daugaard G, E Skakkebaek N, Stenwig AE, Nesland JM, Looijenga LH, Oosterhuis JW. Testicular carcinoma in situ in patients with extragonadal germ-cell tumours: the clinical role of pretreatment biopsy. Ann Oncol 2003; 14: 1412-1418.

61. Levin HS. Tumors of the testis in intersex syndromes. Urol Clin North Am 2000; 27: 543-551.

62. Hasle H, Clemmensen IH, Mikkelsen M. Risks of leukaemia and solid tumours in individuals with Down's syndrome. Lancet 2000; 355: 165-169.

63. Satgé D, Sasco AJ, Curé H, Leduc B, Sommelet D, Vekemans MJ. An excess of testicular germ cell tumors in Down's syndrome: three case reports and a review of the literature. Cancer 1997; 80: $929-935$

64. Lutke Holzik MF, Siimons RH, Sleijfer DT, Sonneveld DJ, HoekstraWeebers JE, van Echten-Arends J, Hoekstra HJ. Syndromic aspects of testicular carcinoma. Cancer 2003; 97: 984-992.

65. Swerdlow AJ, De Stavola BL, Swanwick MA, Maconochie NE. Risks of breast and testicular cancers in young adult twins in England and Wales: evidence on prenatal and genetic aetiology. Lancet 1997; 350: 1723-1728.
66. Sharpe RM. The 'oestrogen hypothesis' - where do we stand now? Int J Androl 2003; 26: 2-15.

67. Braun MM, Caporaso NE, Page WF, Hoover RN. Prevalence of a history of testicular cancer in a cohort of elderly twins. Acta Genet Med Gemellol (Roma) 1995; 44: 189-192.

68. Dieckmann KP, Endsin G, Pichlmeier U. How valid is the prenatal estrogen excess hypothesis of testicular germ cell cancer? A case control study on hormone-related factors. Eur Urol 2001; 40: 677-683.

69. Nicholson PW, Harland SJ. Inheritance and testicular cancer. Br J Cancer 1995; 71: 421-426.

70. Heimdal K, Olsson H, Tretli S, Fosså SD, Børresen AL, Bishop DT. A segregation analysis of testicular cancer based on Norwegian and Swedish families. Br J Cancer 1997; 75: 1084-1087.

71. Møller H. Trends in sex-ratio, testicular cancer and male reproductive hazards: are they connected? APMIS 1998; 106 : 232-238

72. Petersen PM, Skakkebaek NE, Giwercman A. Gonadal function in men with testicular cancer: biological and clinical aspects. APMIS 1998; 106: 24-34.

73. Sonneveld DJ, Hoekstra HJ, van der Graaf WT, Sluiter WJ, Mulder $\mathrm{NH}$, Willemse PH, Koops HS, Sleijfer DT. Improved long term survival of patients with metastatic nonseminomatous testicular germ cell carcinoma in relation to prognostic classification systems during the cisplatin era. Cancer 2001; 91: 1304-1315.

74. Sonneveld DJ, Lutke Holzik MF, Nolte IM, Sleijfer DT, van der Graaf WT, Bruinenberg M, Siimons RH, Hoekstra HJ, Te Meerman GJ. Testicular carcinoma and HLA Class II genes. Cancer 2002; 95: 1857-1863.

75. Özdemir E, Kakehi Y, Mishina M, Ogawa O, Okada Y, Özdemir D, Yoshida O. High-resolution HLA-DRB1 and DQB1 genotyping in Japanese patients with testicular germ cell carcinoma. Br J Cancer 1997; 76: 1348-1352.

76. Rapley EA, Crockford GP, Teare D, Biggs P, Seal S, Barfoot R, Edwards S, Hamoudi R, Heimdal K, Fossâ SD, Tucker K, Donald J, Collins F, Friedlander M, Hogg D, Goss P, Heidenreich A, Ormiston W, Daly PA, Forman D, Oliver TD, Leahy M, Huddart R, Cooper CS, Bodmer JG, Easton DF, Stratton MR, Bishop DT. Localization to Xq27 of a susceptibility gene for testicular germ-cell tumours. Nat Genet 2000; 24: 197-200.

77. Rapley EA, Crockford GP, Easton D, Stratton MR, Bishop DT; International Testicular Cancer Linkage Consortium. Localisation of susceptibility genes for familial testicular germ cell tumour. APMIS 2003; 111: 128-135.

78. Lutke Holzik MF, Hoekstra HJ, Sijmons RH, Sonneveld DJ, van der Steege G, Sleiifer DT, Nolte IM. Re-analysis of the Xq27-Xq28 region suggests a weak association of an $X$-linked gene with sporadic testicular germ cell tumour without cryptorchidism. Eur J Cancer 2006; 42: 1869-1874.

79. Austoker J. Screening for ovarian, prostatic, and testicular cancers. BMJ 1994; 309: 315-320

80. Moiseyenko VM, Danilov AO, Baldueva IA, Danilova AB, Tyukavina NV, Larin SS, Kiselev SL, Orlova RV, Anisimov WV, Semenova Al, Shchekina LA, Gafton GI, Kochnev VA, Barchuk AS, Kanaev SV, Hanson KP, Georgiev GP. Phase I/II trial of gene therapy with autologous tumor cells modified with tag7/PGRP-S gene in patients with disseminated solid tumors: miscellaneous tumors. Ann Oncol 2005; 16: 162-168.

81. Risch N, Merikangas K. The future of genetic studies of complex human diseases. Science 1996; 273: 1516-1517.

82. Youngren KK, Nadeau JH, Matin A. Testicular cancer susceptibility in the 129.MOLF-Chr19 mouse strain: additive effects, gene interactions and epigenetic modifications. Hum Mol Genet 2003; 12: $389-398$ 